\title{
MOG transmembrane and cytoplasmic domains contain highly stimulatory T-cell epitopes in MS \\ OPEN
}

Michel Varrin-Doyer,

$\mathrm{PhD}$

Aparna Shetty, PhD

Collin M. Spencer, BS

Ulf Schulze-Topphoff,

$\mathrm{PhD}$

Martin S. Weber, MD

Claude C.A. Bernard,

$\mathrm{PhD}$

Thomas Forsthuber, MD,

$\mathrm{PhD}$

Bruce A.C. Cree, MD,

$\mathrm{PhD}$, MAS

Anthony J. Slavin, $\mathrm{PhD}$

Scott S. Zamvil, MD,

$\mathrm{PhD}, \mathrm{FAAN}$

Correspondence to

Dr. Zamvil:

zamvil@ucsf.neuroimmunol.org

\section{See companion article}

\section{ABSTRACT}

Objective: Recently, we reported that the 218 amino acid murine full-length myelin oligodendrocyte glycoprotein (MOG) contains novel T-cell epitopes p119-132, p181-195, and p186-200, located within its transmembrane and cytoplasmic domains, and that p119-132 is its immunodominant encephalitogenic T-cell epitope in mice. Here, we investigated whether the corresponding human MOG sequences contain T-cell epitopes in patients with multiple sclerosis (MS) and healthy controls ( $\mathrm{HC})$.

Methods: Peripheral blood T cells from patients with MS and HC were examined for proliferation to MOG p119-130, p181-195, p186-200, and p35-55 by fluorescence-activated cell sorting analysis using carboxylfluorescein diacetate succinimidyl ester dilution assay. Intracellular production of proinflammatory cytokines was analyzed by flow cytometry.

Results: MOG p119-130, p181-195, and p186-200 elicited significantly greater T-cell responses than $\mathrm{p35}-55$ in patients with MS. T cells from patients with MS proliferated significantly more strongly to MOG p119-130 and p186-200 than did T cells from HC. Further, MOG p119-130-specific T cells exhibited Th17 polarization, suggesting this T-cell epitope may be relevant to MS pathogenesis.

Conclusions: Transmembrane and cytoplasmic MOG domains contain potent T-cell epitopes in MS. Recognition of these determinants is important when evaluating T-cell responses to MOG in MS and may have implications for development of myelin antigen-based therapeutics. Neurol Neuroimmunol Neuroinflammation 2014;1:e20; doi: 10.1212/NXI.0000000000000020

\section{GLOSSARY}

aa $=$ amino acid(s); AQP4 $=$ aquaporin-4; CFSE $=$ carboxylfluorescein diacetate succinimidyl ester; $\mathbf{E A E}=$ experimental autoimmune encephalitis; HC = healthy controls; Ig = immunoglobulin; $\mathbf{M B P}=$ myelin basic protein; $\mathbf{M H C}=$ major histocompatibility complex; $\mathbf{M O G}$ = myelin oligodendrocyte glycoprotein; $\mathbf{M S}=$ multiple sclerosis; $\mathbf{N M O}=$ neuromyelitis optica; $\mathbf{P L P}=$ proteolipid protein; PBMC = peripheral blood mononuclear cells; UCSF = University of California at San Francisco.

Evidence indicates that $\mathrm{T}$ cells specific for myelin autoantigens have an important role in the pathogenesis of multiple sclerosis (MS). ${ }^{1}$ Although several myelin antigens exist, investigations of T-cell reactivity in MS have focused attention on myelin basic protein (MBP) and proteolipid protein (PLP), which account for approximately $80 \%$ of myelin protein, ${ }^{2}$ as well as myelin oligodendrocyte glycoprotein (MOG). Although intact MOG protein accounts for only $0.05 \%-0.1 \%$ of total myelin proteins, ${ }^{2}$ it was initially reported to induce more potent T-cell responses than other myelin antigens in patients with MS. ${ }^{3}$ Subsequent studies in MS have concentrated primarily on $\mathrm{T}$-cell recognition of the 117 amino acid (aa) N-terminal extracellular immunoglobulin (Ig) "variable-like" domain of MOG but have not consistently observed T-cell responses. ${ }^{4}$ However, native full-length MOG is 218 aa and contains transmembrane and cytoplasmic domains. ${ }^{5}$ In our companion manuscript, we identified 3 T-cell MOG determinants in mice, MOG p119-132, located within the transmembrane region, which induced potent clinical and histologic experimental autoimmune encephalitis (EAE), and MOG p181-195 and p186-200,

From the Department of Neurology and Program in Immunology (M.V.-D., A.S., C.M.S., U.S.-T., B.A.C.C., S.S.Z.), University of California, San Francisco; Department of Neuropathology and Department of Neurology (M.S.W.), University Medical Center, Georg-August University, Göttingen, Germany; Multiple Sclerosis Research Group (C.C.A.B.), Australian Regenerative Medicine Institute, Monash University, Clayton, Victoria, Australia; Department of Immunology (T.F.), University of Texas at San Antonio; and Boehringer Ingelheim (A.J.S.), Ridgefield, CT. Go to Neurology.org/nn for full disclosures. Funding information and disclosures deemed relevant by the authors, if any, are provided at the end of the article. The Article Processing Charge was paid by the authors.

This is an open access article distributed under the terms of the Creative Commons Attribution-Noncommercial No Derivative 3.0 License, which permits downloading and sharing the work provided it is properly cited. The work cannot be changed in any way or used commercially. 
2 discrete T-cell epitopes within the cytoplasmic domain. ${ }^{6}$ Upon recall to immunization of mice with full-length MOG, these T-cell epitopes were recognized more frequently than MOG p35-55, indicating they are dominant epitopes. We therefore questioned whether $\mathrm{T}$ cells in patients with MS recognize the corresponding peptide sequences of human MOG.

METHODS Patients. Twelve Caucasian patients with MS (66\% female, mean age [SD]: 43.2 [12.9] years, mean disease duration [SD]: 5.5 [6.2] years, mean Expanded Disability Status Scale score [SD]: 1.8 [1.0]) and 12 Caucasian healthy controls (HC) $(42 \%$ female, mean age $[\mathrm{SD}]: 40.5$ [8.8] years) were recruited from the University of California at San Francisco (UCSF) MS Center. Out of 12 patients with MS, 10 had not received disease-modifying therapies prior to the study and 2 were treated with rituximab. Statistical significance between patients with MS and HC occurred regardless of whether the 2 patients treated with rituximab were included in T-cell proliferation and cytokine analysis. None of the patients had received steroids within 2 months preceding blood draws. Blood was collected by venipuncture.

Standard protocol approvals, registrations, and patient consents. This study was approved by the UCSF Committee on Human Research (Protocol 10-00650). Written informed consent was obtained from participants prior to enrollment.

Peptides. Human MOG p119-130 (FYWVSPGVLVLL), MOG p181-195 (TLFVIVPVLGPLVAL), and p186-200 (VPVLGPLVALIICYN) were synthesized by Genemed Synthesis Inc. (San Antonio, TX). Human MOG p35-55 (MEVGWYRPPFSRVVHLYRNGK) was purchased from AnaSpec, Inc. (Fremont, CA).

Lymphocyte culture and proliferation assay. Human peripheral blood mononuclear cells (PBMC) were isolated by density gradient centrifugation over Ficoll (Ficoll-Paque PLUS; GE Healthcare, Milwaukee, WI). T-cell proliferation was evaluated as previously described. ${ }^{7}$ PBMC were stained with $0.5 \mu \mathrm{M} 5$,6carboxylfluorescein diacetate succinimidyl ester (CFSE) (Invitrogen, Carlsbad, CA). After 10 days of culture with antigens, T-cell proliferation was examined by flow cytometric evaluation of CFSE dilution. Proliferation was expressed as the cell division index (defined as the number of CFSE ${ }^{\text {low }} \mathrm{T}$ cells cultured with antigen/number of CFSE ${ }^{\text {low }} \mathrm{T}$ cells without antigen). Culture medium consisted of X-VIVO 15 (Lonza, Walkersville, MD) supplemented with penicillin $(100 \mathrm{U} / \mathrm{mL})$ and streptomycin $(0.1$ $\mathrm{mg} / \mathrm{mL}$ ). Mouse monoclonal anti-HLA-DR (clone G46-6; BD Biosciences, San Jose, CA), anti-HLA-DQ (clone HG-38; Abcam, Cambridge, MA), anti-HLA-DP (clone B7/21; Abcam), and isotype control (clone G155-178; BD Biosciences) were used to evaluate inhibition of T-cell proliferation. Antibodies were added to CFSE-stained PBMC cultures 1 hour prior to antigen addition.

Flow cytometry analysis. Human single-cell suspensions were stained with antibodies against CD3 and CD4 (eBioscience, San Diego, CA and BD Biosciences). Intracellular cytokine production by $\mathrm{CD}^{+} \mathrm{T}$ cells was analyzed by monitoring the expression of interferon- $\gamma$ and interleukin-17 (1:100) (eBioscience) after phorbol 12-myristate 13-acetate $(50 \mathrm{ng} / \mathrm{mL})$ and ionomycin $(500$ $\mathrm{ng} / \mathrm{mL}$; both from Sigma-Aldrich, St. Louis, MO) stimulation for
5 hours in the presence of GolgiPlug (BD Biosciences). Data were acquired on a FACSCanto flow cytometer (BD Biosciences).

Statistics. Statistical analysis was performed using Prism (GraphPad Software, La Jolla, CA) software. The nonparametric MannWhitney $U$ test was used to compare data. A value of $p<0.05$ was considered statistically significant.

RESULTS Peripheral blood $\mathrm{CD}^{+} \mathrm{T}$ cells from patients with MS and $\mathrm{HC}$ were examined for their capability to respond to human MOG peptides p119130, p181-195, and p186-200. Proliferation was measured by CFSE dilution assay. As shown in figure $1 \mathrm{~A}, \mathrm{CD}^{+}{ }^{+} \mathrm{T}$ cells from untreated patients with $\mathrm{MS}$ and HC proliferated in response to human MOG p119-130, p181-195, and p186-200 more strongly than to MOG p35-55. Further, T-cell proliferation to p119-130, p181195 , and p186-200 was significantly greater than to $\mathrm{p} 35$ $55(p=0.0051, p=0.0304$, and $p=0.0007$, respectively) in patients with MS. Proliferative responses to MOG p119-130 and p186-200 were most robust, and, in comparison, $\mathrm{T}$ cells from patients with MS proliferated significantly more to these determinants than $T$ cells from HC. In contrast, no significant differences in proliferation to p181-195 were observed between patients with MS and HC.

In MS, the pathogenic involvement of $\mathrm{CD}^{+}{ }^{+} \mathrm{T}$ cells is supported by the association between disease susceptibility and major histocompatibility complex (MHC)-II genes. ${ }^{1}$ Using MHC II-blocking antibodies, we observed that T-cell proliferation to MOG p119130 and p186-200 was inhibited by anti-HLA-DR but was not significantly inhibited by anti-HLA-DQ or anti-HLA-DP. These results demonstrated that HLA-DR molecules serve as restriction elements for p119-130 - and p186-200-specific T cells (figure 1B).

Th1 and Th17 cells represent 2 proinflammatory T-cell subsets that may participate in MS pathogenesis. Thus, we examined proliferating MOG peptidespecific $\mathrm{T}$ cells for production of proinflammatory cytokines. The frequency of Th17 cells and ratio of Th17 to Th1 cells were greater in response to MOG p119-130 than to the other MOG T-cell determinants examined (figure 2). Further, Th17 p119-130-specific T cells were statistically more frequent in patients with MS than HC. In contrast, the frequency of MOG p186200-specific Th1 cells appeared to be higher in patients with MS than HC, but it did not reach statistical significance. Collectively, these results clearly demonstrate that the T-cell determinants within the transmembrane and cytoplasmic domains of MOG, shared in mice and humans, are highly stimulatory in patients with MS.

DISCUSSION In 1993, when MOG protein was discovered as a CNS autoantigen, it was reported to induce more potent T-cell responses than MBP, PLP, or myelin-associated glycoprotein (MAG). ${ }^{3}$ However, 
A

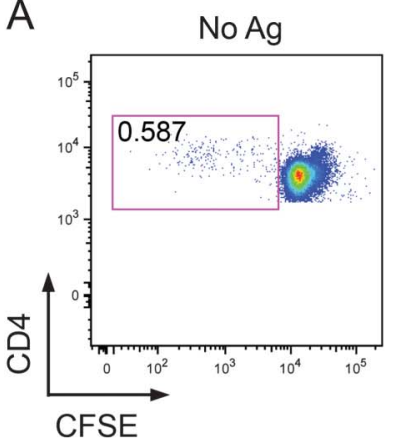

p35-55

CFSE
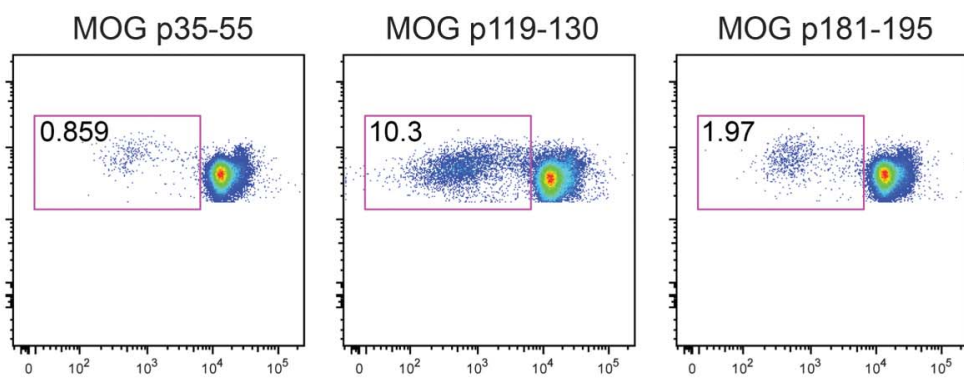

MOG p186-200

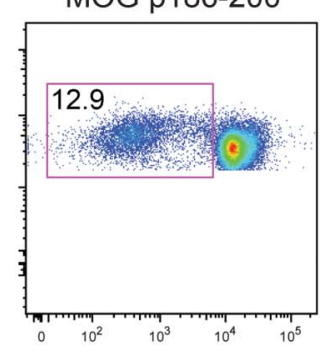

p119-130

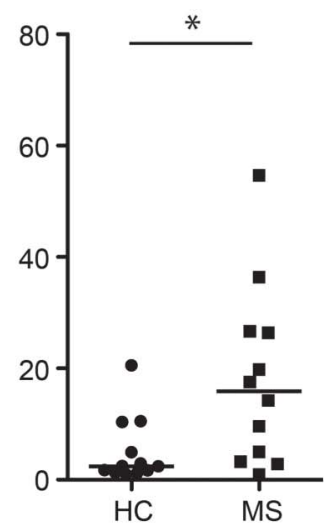

p181-195



p186-200

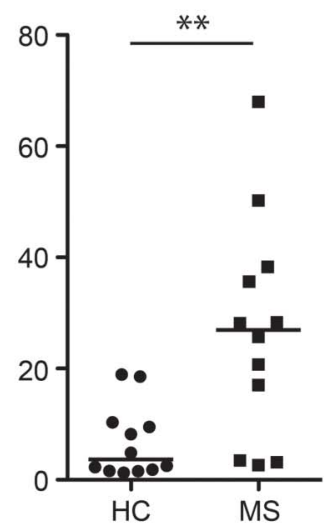

B


(A) Peripheral blood mononuclear cells (PBMC) from 12 patients with multiple sclerosis (MS) and 12 healthy controls (HC) were examined by carboxylfluorescein diacetate succinimidyl ester (CFSE) dilution assay for proliferation to myelin oligodendrocyte glycoprotein (MOG) p35-55, p119-130, p181-195, and p186-200 $(10 \mu \mathrm{g} / \mathrm{mL})$ after 10 days of culture. CFSE was measured in CD3 ${ }^{+}$CD4 ${ }^{+}$T cells by flow cytometry and quantified by cell division index (CDI). Horizontal lines indicate median values. (B) CFSE-labeled PBMC were cultured for 10 days in the presence of antigens alone or in combination with anti-HLA-DR, -anti-HLA-DQ, anti--HLA-DP, or isotype control antibodies. T-cell proliferative responses were evaluated by analysis of CFSE dilution. $* p<0.05, * * p<0.01$, Mann-Whitney $U$ test.

most subsequent studies utilized peptides corresponding to the extracellular MOG domain $\left(\mathrm{MOG}^{1-125}\right)$ or recombinant $\mathrm{MOG}^{1-125}$ itself and did not consistently observe T-cell reactivity. ${ }^{4}$ These findings raised the possibility that T-cell epitopes exist in the other domains. In contrast to many studies that evaluated T-cell proliferation to MOG in MS, we utilized the CFSE dilution assay, which is a sensitive and robust method for measuring 

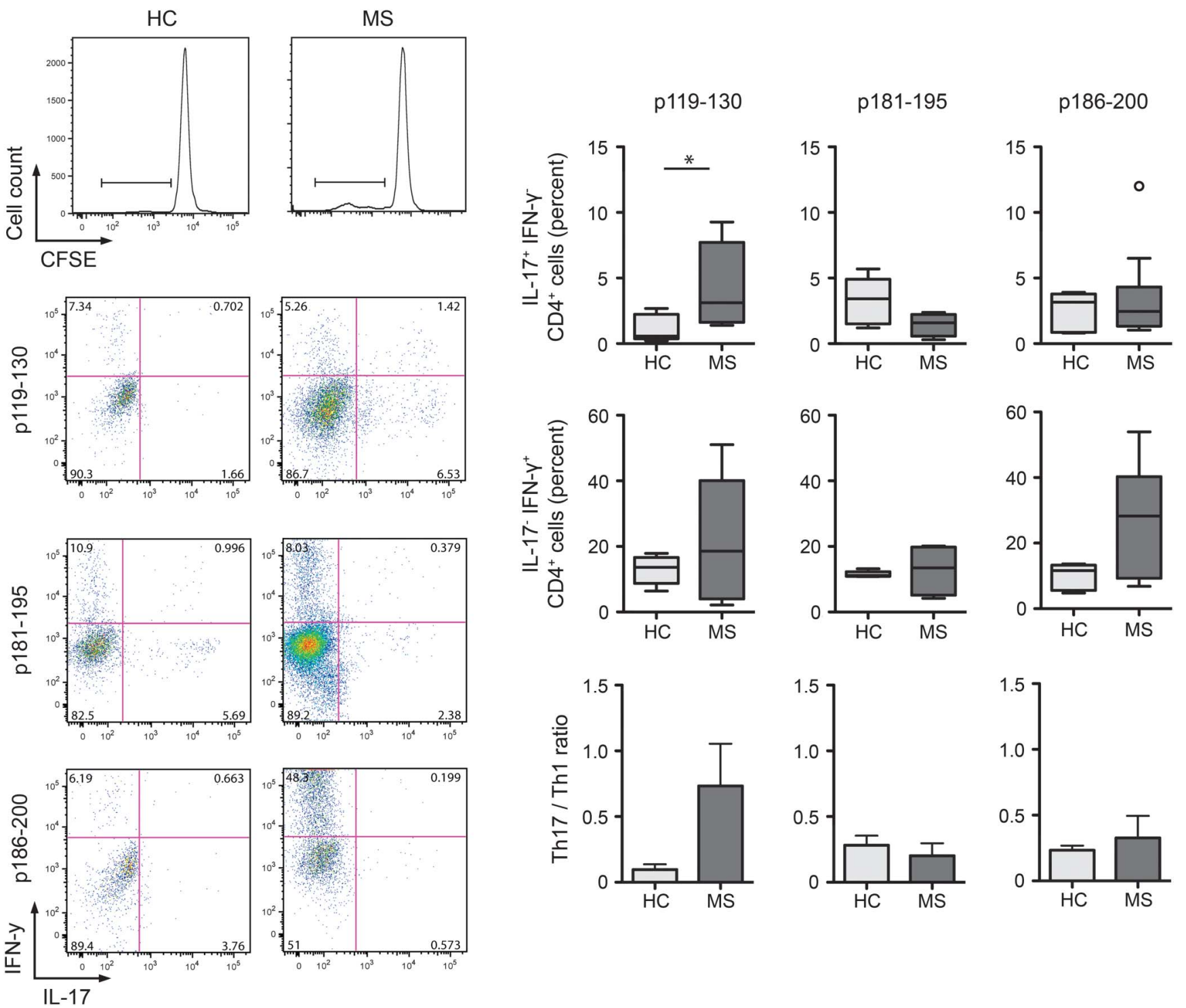

CD4 ${ }^{+}$CFSElow proliferating T cells (cell division index $>2$ ) were analyzed for interleukin (IL)-17 and interferon (IFN)- $\gamma$ production by intracellular staining after stimulation with phorbol 12-myristate 13-acetate/ionomycin for 5 hours. Frequencies of IL17+ IFN- $\gamma^{-}, I L 17^{+}$IFN- $\gamma^{+}$, and IL17-IFN- $\gamma^{+}$were examined among proliferating p119-130-specific CD4 ${ }^{+} \mathrm{T}$ cells, p181-195-specific CD4 ${ }^{+} \mathrm{T}$ cells, and p186-200-specific CD4+ $\mathrm{T}$ cells. Frequencies of IL-17 and IFN- $\gamma$ single positive T cells were used to calculate Th17/Th1 ratio. Box and whisker plots include the median, distribution, and range. $* p<0.05$, Mann-Whitney $U$ test. CFSE $=$ carboxylfluorescein diacetate succinimidyl ester; $\mathrm{HC}=$ healthy controls.

T-cell proliferation. In our study, the 3 transmembrane or cytoplasmic determinants examined elicited stronger T-cell proliferative responses than human MOG p35-55. These observations suggest that MOG p119-130, identified in our accompanying manuscript as an encephalitogenic murine T-cell determinant, may be pathologically relevant in both EAE and MS.

Of interest, a small number of reports that did evaluate T-cell reactivity to peptides corresponding to the intracellular domain of MOG observed similar, or lower, responses in patients with MS than $\mathrm{HC}^{8,9}$ Here, we observed not only that MOG p119-130 and p186-200 elicited more vigorous T-cell responses than $\mathrm{p} 35-55$ but also that these 2 novel T-cell epitopes elicited stronger proliferative responses in patients with MS than HC. In addition, p119-130-specific T cells exhibited significant proinflammatory Th17 polarization. Our demonstration that immunodominant T-cell epitopes exist within the C-terminal 100 residues of intact MOG in mice and that they correspond to determinants in MS should encourage reevaluation of T-cell recognition of MOG in patients with MS.

Two recent studies suggested that MOG-specific IgG antibodies may define a subset of aquaporin- 4 (AQP4)-seronegative patients with neuromyelitis optica (NMO), ${ }^{10,11}$ considered an astrocytopathy. IgG is a T cell-dependent antibody subclass. ${ }^{7}$ While it should be recognized that astroglial histopathology is necessary 
to confirm that this entity indeed represents NMO, it may also be important to evaluate $\mathrm{T}$-cell responses to the immunodominant determinants of MOG in patients with NMO. It is interesting that a murine model containing $\mathrm{T}$ cells and $\mathrm{B}$ cells that selectively target MOG, a protein expressed on oligodendrocytes and not astrocytes, leads to opticospinal EAE. ${ }^{12}$ Thus, one can speculate that $\mathrm{MOG}_{\mathrm{IgG}}{ }^{+} \mathrm{AQP} 4$-seronegative $\mathrm{NMO}$ could represent a unique form of opticospinal MS.

While myelin antigen-based tolerogenic therapies, including altered peptide ligands, DNA vaccination, intravenous peptide administration, and oral tolerance, have not clearly proven efficacious in phase II and III MS trials, interest in development of therapies that target autoantigen-specific immune cells remains high. ${ }^{13}$ Of interest, a majority of such studies have tested therapies targeting immune recognition of MBP alone, ${ }^{13}$ and those investigations that did include MOG concentrated on T-cell epitopes within its extracellular domain. ${ }^{14}$ Our observations that the transmembrane and cytoplasmic domains of MOG contain highly stimulatory T-cell epitopes in patients with MS underscore the importance of including these domains should myelin antigen-based therapies be further advanced in MS. Further, recognition of these T-cell epitopes of MOG is clearly important when evaluating how established and novel MS therapeutics influence T-cell recognition of CNS autoantigens.

\section{AUTHOR CONTRIBUTIONS}

M.V.-D. and S.S.Z. designed the study and analyzed data. M.V.-D., A.S., and S.S.Z. wrote the paper. M.V.-D., C.M.S., and U.S.-T. performed the experiments. M.S.W., T.F., C.C.A.B., and A.J.S. gave conceptual advice and discussed the results. B.A.C.C. contributed patient samples. S.S.Z. supervised the study.

\section{STUDY FUNDING}

Supported by grants to S.S.Z. from the NIH (RO1 AI073737 and RO1 NS063008), National Multiple Sclerosis Society (NMSS) (RG 4124), Guthy Jackson Charitable Foundation, Maisin Foundation, and Boehringer Ingelheim. C.C.A.B. was supported by grants from the Baker Foundation, the Victoria/CIRM Joint Project (RMI-01739), the Medical Research Council of Australia, and the NMSS (RG3844A2/1).

\section{DISCLOSURE}

M. Varrin-Doyer received a travel grant from Teva Pharmaceuticals and research support from NMSS. A. Shetty reports no disclosures and C.M. Spencer report no disclosures. U. Schulze-Topphoff is an employee of Silence Therapeutics GmbH. M.S. Weber is on the editorial board for Plos One; C.C.A. Bernard is on the editorial board for Future Neurology and was a guest editor for Inflammation and Regeneration; and receives research support from NHMRC of Australia, the Victorian Government, and Eva and Les Erdi AUSiMED Fellowship in Neurological Diseases. T. Forsthuber is on the editorial board for Immunotherapy, is an associate editor for Plos One, is an editor for Frontiers Multiple Sclerosis and Neuroimmunology, is senior editor for the Journal of Immunology and Expert Review for Clinical Immunology, and receives research support from the National MS Society. B.A.C. Cree is an editor for Annals of Neurology; has consulted for Abbvie, Biogen Idec, EMD Serono, Genzyme, Novartis, Sanofi Aventis, and Teva Neurosciences; and has received research support from Acorda, Avanir, Biogen Idec, EMD Serono, Hoffman La Roche, and Novartis. A.J. Slavin is an employee of Abbvie Bioresearch Center and was formerly an employee of Boehringer Ingelheim Pharmaceuticals. S.S. Zamvil has served on the Data Safety Monitoring Boards for MS trials conducted by BioMS, Teva Pharmaceuticals Inc, Opexa Therapeutics, and Eli Lilly and Co; is an associate editor for Neurology: Neuroimmunology \& Neuroinflammation and the Journal of the Neurological Sciences; has received honoraria from Eli Lilly and Co, BiogenIdec, Teva Neuroscience, and EMD Serono; has consulted for Biogen Idec, Teva Neuroscience, EMD Serono, Genzyme, and Novartis; is on the speakers' bureaus for Advanced Health Media and Biogen; and has received research support from Boehringer Ingelheim, NIH, NMSS, and Guthy Jackson Charitable Foundation. Go to Neurology.org/nn for full disclosures.

Received April 30, 2014. Accepted in final form July 8, 2014.

\section{REFERENCES}

1. Sospedra M, Martin R. Immunology of multiple sclerosis. Annu Rev Immunol 2005;23:683-747.

2. Amiguet P, Gardinier MV, Zanetta JP, Matthieu JM. Purification and partial structural and functional characterization of mouse myelin/oligodendrocyte glycoprotein. J Neurochem 1992;58:1676-1682.

3. Kerlero de Rosbo N, Milo R, Lees MB, Burger D, Bernard CC, Ben-Nun A. Reactivity to myelin antigens in multiple sclerosis. Peripheral blood lymphocytes respond predominantly to myelin oligodendrocyte glycoprotein. J Clin Invest 1993;92:2602-2608.

4. Elong Ngono A, Pettre S, Salou M, et al. Frequency of circulating autoreactive $\mathrm{T}$ cells committed to myelin determinants in relapsing-remitting multiple sclerosis patients. Clin Immunol 2012;144:117-126.

5. Pham-Dinh D, Allinquant B, Ruberg M, Della Gaspera B, Nussbaum JL, Dautigny A. Characterization and expression of the cDNA coding for the human myelin/oligodendrocyte glycoprotein. J Neurochem 1994;63:2353-2356.

6. Shetty A, Gupta SG, Varrin-Doyer M, et al. Immunodominant T-cell epitopes of MOG reside in its transmembrane and cytoplasmic domains in EAE. Neurol Neuroimmunol Neuroinflammation 2014;1:e22; doi: 10.1212/NXI.0000000000000022

7. Varrin-Doyer M, Spencer CM, Schulze-Topphoff U, et al. Aquaporin 4-specific $\mathrm{T}$ cells in neuromyelitis optica exhibit a Th17 bias and recognize Clostridium ABC transporter. Ann Neurol 2012;72:53-64.

8. Tejada-Simon MV, Hong J, Rivera VM, Zhang JZ. Skewed autoantibody reactivity to the extracellular domain of myelin oligodendrocyte glycoprotein in multiple sclerosis. Immunology 2002;107:403-410.

9. Weissert R, Kuhle J, de Graaf KL, et al. High immunogenicity of intracellular myelin oligodendrocyte glycoprotein epitopes. J Immunol 2002;169:548-556.

10. Kitley J, Waters P, Woodhall M, et al. Neuromyelitis optica spectrum disorders with aquaporin-4 and myelinoligodendrocyte glycoprotein antibodies: a comparative study. JAMA Neurol 2014;71:276-283.

11. Sato DK, Callegaro D, Lana-Peixoto MA, et al. Distinction between MOG antibody-positive and AQP4 antibody-positive NMO spectrum disorders. Neurology 2014;82:474-481.

12. Molnarfi N, Schulze-Topphoff U, Weber MS, et al. MHC class II-dependent B cell APC function is required for induction of CNS autoimmunity independent of myelin-specific antibodies. J Exp Med 2013;210:2921-2937.

13. Steinman L. Antigen-specific therapy of multiple sclerosis: the long-sought magic bullet. Neurotherapeutics 2007;4:661-665.

14. Jurynczyk M, Walczak A, Jurewicz A, JesionekKupnicka D, Szczepanik M, Selmaj K. Immune regulation of multiple sclerosis by transdermally applied myelin peptides. Ann Neurol 2010;68:593-601. 


\title{
Neurology $^{\odot}$ \\ Neuroimmunology \& Neuroinflammation
}

\author{
MOG transmembrane and cytoplasmic domains contain highly stimulatory T-cell \\ epitopes in MS \\ Michel Varrin-Doyer, Aparna Shetty, Collin M. Spencer, et al. \\ Neurol Neuroimmunol Neuroinflamm 2014;1; \\ DOI 10.1212/NXI.0000000000000020
}

This information is current as of August 14, 2014

\section{Updated Information \& Services}

References

Citations

Subspecialty Collections

Permissions \& Licensing

Reprints including high resolution figures, can be found at: http://nn.neurology.org/content/1/2/e20.full.html

This article cites 13 articles, 2 of which you can access for free at: http://nn.neurology.org/content/1/2/e20.full.html\#\#ref-list-1

This article has been cited by 2 HighWire-hosted articles: http://nn.neurology.org/content/1/2/e20.full.html\#\#otherarticles

This article, along with others on similar topics, appears in the following collection(s):

All Immunology

http://nn.neurology.org//cgi/collection/all_immunology

Autoimmune diseases

http://nn.neurology.org//cgi/collection/autoimmune_diseases Multiple sclerosis

http://nn.neurology.org//cgi/collection/multiple_sclerosis

Information about reproducing this article in parts (figures,tables) or in its entirety can be found online at:

http://nn.neurology.org/misc/about.xhtml\#permissions

Information about ordering reprints can be found online: http://nn.neurology.org/misc/addir.xhtml\#reprintsus

Neurol Neuroimmunol Neuroinflamm is an official journal of the American Academy of Neurology.

Published since April 2014, it is an open-access, online-only, continuous publication journal. Copyright $\odot$ 2014 American Academy of Neurology. All rights reserved. Online ISSN: 2332-7812.

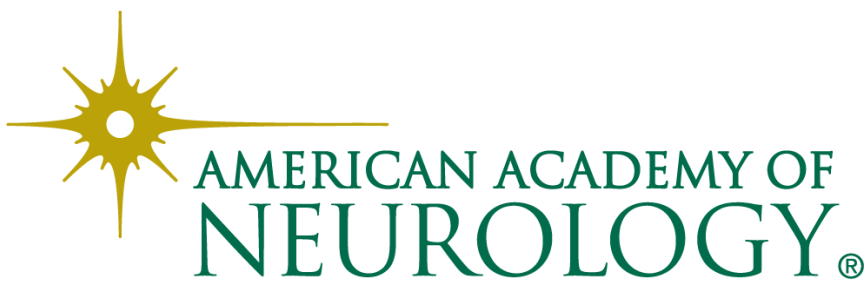

